\title{
Analisis Faktor Erodibilitas Tanah Penyebab Erosi di Area Tambang Site Melak
}

\author{
Arisdiansyah Putra ${ }^{1, a)}$, Ratna Widyaningsih ${ }^{2)}$, M. Nurcholis ${ }^{3)}$ \\ 1) Teknik Pertambangan, Fakultas Teknologi Mineral, UPN Veteran Yogyakarta \\ 2) Teknik Perminyakan, Fakultas Teknologi Mineral, UPN Veteran Yogyakarta \\ 3) Ilmu Tanah, Fakultas Pertanian, UPN Veteran Yogyakarta \\ a) Email korespondensi : arisdiansyahputra@rocketmail.com
}

\begin{abstract}
ABSTRAK
Penambangan batubara secara terbuka seperti yang dilakukan oleh perusahaan tambang batubara site Melak memberikan dampak negatif terhadap lingkungan alam sekitar. Dampak yang terjadi dari operasi penambangan adalah lahan menjadi tidak produktif serta tingkat erosi yang sangat tinggi karena vegetasi di atas lahan bekas penambangan telah hilang. Hal tersebut yang mempengaruhi kepekaan tanah untuk bertahan terhadap penghancuran dan pengangkutan oleh hujan dan aliran permukaan serta terjadinya longsoran. Analisis faktor erodibilitas tanah dilihat dari sifat fisik-kimia tanah yang menjadi salah satu penyebab erosi dengan menggunakan parameter unsur organik, struktur tanah, permeabilitas, tekstur. Lokasi observasi dilakukan pada lereng disposal dan low wall in pit yang telah di revegetasi dengan teknik hydroseeding. Penelitian ini dilakukan dengan membuat desain plot erosi dan sedimentasi berbentuk kotak dengan pembatas seng ukuran 2 x 2 m2, dimana setiap kotak dibagi menjadi 3 kolom. Pembagian 3 kolom pada setiap kotak dilakukan untuk mendapatkan data pengulangan yang representative. Pengambilan sample tanah dilakukan di setiap kotak dengan menggunakan ring sample.
\end{abstract}

Kata Kunci: erosi; erodibilitas; sampel tanah; sifat fisik-kimia tanah

\begin{abstract}
Open-pit coal mining as done by the coal mining site Melak have a impact on the surrounding natural environment. The impact of mining operations is that the land becomes unproductive and erosion is very high because of loosing its vegetation on ex-mining land. Vegetation influence the sensitivity of the soil to withstand destruction and transportation by rain and surface runoff and the occurrence of landslides. Analysis of soil erodibility factors seen from the physical-chemical properties of soil is one of the causes of erosion by using organic element parameters, soil structure, permeability, texture. The observation location was carried out on the disposal slope and low wall in-pit that has been revegetation with the hydroseeding technique. This research was carried out by making a design of erosion and sedimentation plots in the form of a zinc boundary measuring $2 \times 2 \mathrm{~m} 2$, each box divides into three columns. The division of three columns in each box is done to get representative repetition data. Taking soil samples is carried out in each box using a sample ring.
\end{abstract}

Keywords: erodability; erosion; physical-chemical characteristics of the soil; soil sample

\section{PENDAHULUAN}

Kegiatan penambangan yang dilakukan dengan cara membuka hutan menyebabkan pengikisan lapisan tanah, pengerukan dan penimbunan (Abu Bakar, 2009). Dampak kerusakan yang ditimbulkan oleh kegiatan penambangan dapat dilihat pada kerusakan lingkungan dan penurunan kualitas lahan yang ditunjukkan dengan adanya penurunan kualitas fisik, kimia dan biologi tanah (Maryani, 2007).

Banyak faktor yang menyebabkan terjadinya erosi diantaranya erosivitas hujan, erodibilitas tanah, panjang dan kemiringan lereng,vegetasi dan manusia (Hudson, 1976). Sifat tanah yang mempengaruhi erodibilitas diantaranya yaitu 1) laju infiltrasi, kapasitas tanah dalam menahan air dan permeabilitas dan 2) ketahanan struktur tanah terhadap dispersi, serta pengikisan tanah oleh butir air hujan dan aliran permukaan (Veiche, 2002).

Area penelitian sebagian besar adalah lahan yang telah dibuka untuk kegiatan penambangan dengan banyak menghasilkan lereng dari kegiatan operasional penambangan. Hal tersebut salah satunya yang menyebabkan terjadinya longsor. Kandungan debu tinggi, liat rendah, dan bahan organik rendah adalah yang paling mudah tererosi (Morgan, 1986). Latar belakang tersebut penulis tertarik untuk melakukan penelitian mengenai faktor erodibilitas tanah penyebab erosi. 


\section{METODE}

Lokasi penelitian ini dilakukan di area konsesi PT.TCM, PIT. 3000 B03. Lokasi penelitian secara administrasi termasuk dalam kecamatan Muara Lawa, Bentian Besar dan Damai, Kabupaten Kutai Barat, Kalimantan Timur. Secara geografis terletak pada $115^{\circ} 38^{\prime} 40.41^{\prime \prime}$ BT dan $0^{\circ} 41^{\prime} 50.06^{\prime \prime}$ LS.

Lokasi tersebut dipilih berdasarkan pertimbangan :

1. Lokasi penelitian mempunyai fungsi penting sebagai area revegetasi juga sebagai penyangga dan resapan air agar tidak terjadi erosi dan longsor di musim hujan.

2. Kondisi ekologis di lokasi penelitian telah mengalami degradasi bahkan sudah mencapai titik kritis dan telah mengalami degradasi akibat erosi disebabkan curah hujan yang terjadi. Gambar 1 menunjukan kondisi lereng yang longsor di lokasi penelitian.

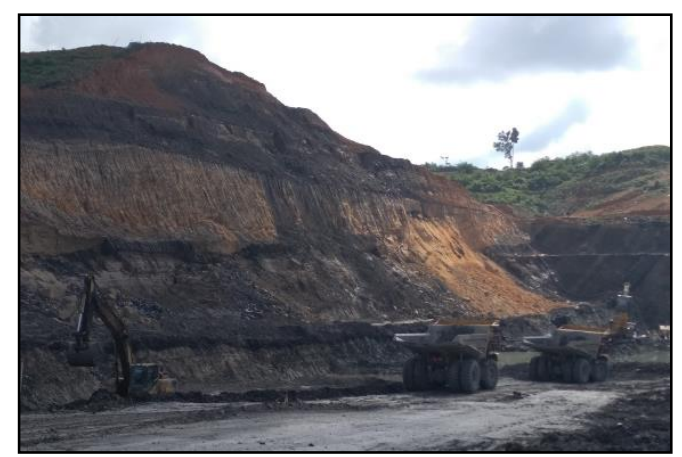

Gambar 1. Kondisi Lereng Lahan Penelitian

\subsection{Metode Petak Kecil}

Metode pengamatan dan pengukuran dilakukan untuk mengetahui efektivitas teknik hydroseeding dikombinasikan dengan material jute net. Pengukuran erosi dan aliran permukaan dilakukan dengan membuat desain plot penyaluran erosi sebagai berikut:

a) Plot erosi dibuat dengan menggunakan petak berbentuk kotak $2 \times 2 \mathrm{~m}^{2}$ (disesuaikan dengan kondisi di lapangan). Plot erosi dibuat menjadi 2 kondisi menggunakan jute net dan non- jute net.

b) Satu kotak dibagi menjadi 3 kolom ukuran $2 \times 0,6 \mathrm{~m}^{2}$ sebagai data pengulangannya.

c) Bagian bawah lereng pada setiap plot dipasang talang air dan ember penampung. Ember ini berfungsi untuk menampung tanah tererosi dan aliran permukaan.

d) Pengamatan dilakukan terhadap erosi dan aliran permukaan yang ditampung dalam ember, erosi ditakar untuk mengetahui volume dan banyaknya sedimen hasil erosi.

e) Selanjutnya sedimen yang diambil dari ember erosi lalu dikeringkan dalam oven dan ditimbang berat kering tanah yang tererosi per satuan luas per hari kejadian hujan.
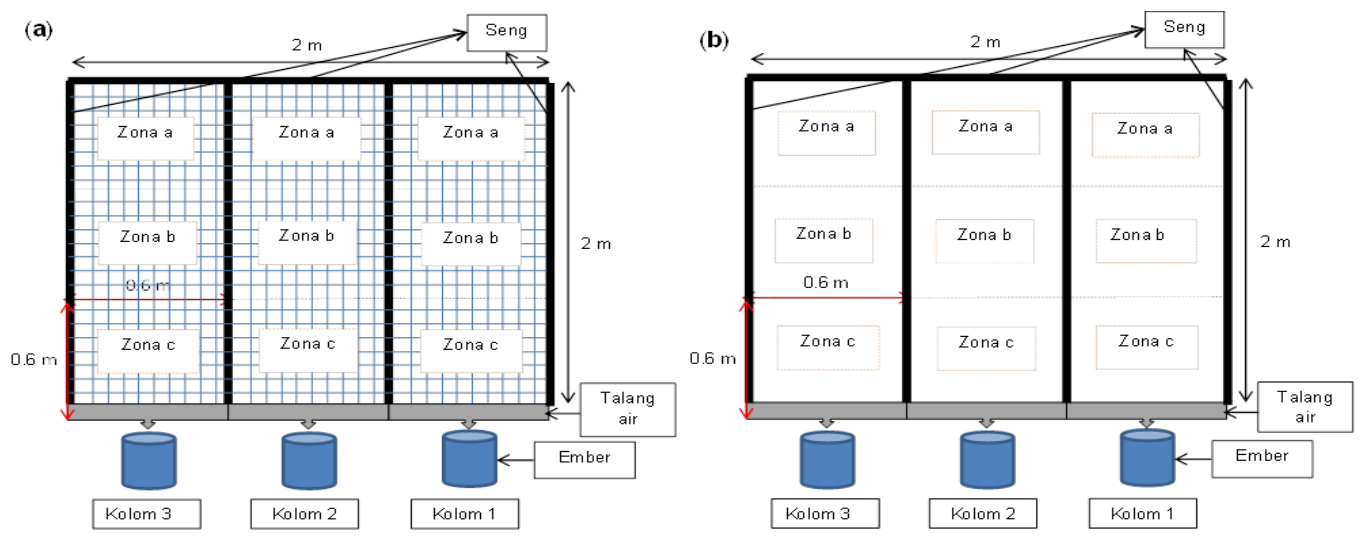

Gambar 2. (a). Plot Penyaluran Erosi Jute net. (b). Plot Penyaluran Erosi Non-Jute net

Pengambilan sampel sedimen dan air dilakukan setiap hari hujan berlangsung menggunakan botol sampel ukuran $200 \mathrm{ml}$. Sampel erosi yang diperoleh kemudian dikeringkan dalam oven dan selanjutnya ditimbang untuk 
mengetahui besarnya erosi per plot desain erosi. Plot penyaluran erosi dapat dilihat pada Gambar 2 dan pemasangan kotak plot erosi dapat dilihat pada Gambar 3.

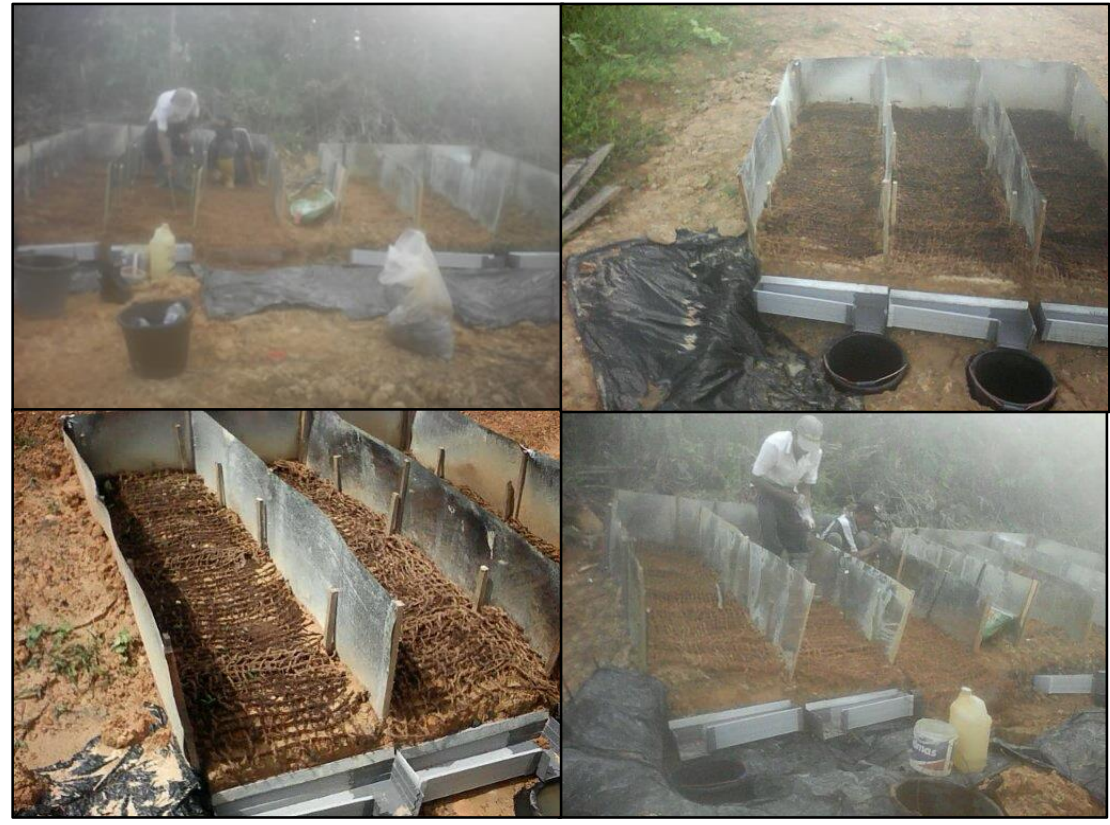

Gambar 3. Pemasangan Kotak Plot Erosi dan Jute Net Pada Lokasi Disposal

Data hasil analisis pengamatan erosi dari aliran permukaan di lapangan kemudian dikumpulkan dan diberi label tanggal dan kode pada tiap plastik sample, selanjutnya dilakukan pengukuran secara aktual dari data setiap sampel yang diperoleh.

\subsection{Pengambilan Sampel Tanah}

Pengamatan dilakukan adalah sebanyak plot pengamatan erosi dan aliran permukaan yaitu 16 unit pengamatan pada kedalaman $0-15 \mathrm{~cm}$. Untuk mengetahui sifat-sifat tanah dilakukan pengamatan langsung di lapangan serta dilakukan pengambilan sampel secara proporsional berupa sampel tanah utuh dan tidak utuh. Tahapan pengambilan sampel tanah utuh sebagai berikut:

1. Pengambilan sampel tanah utuh dilakukan dengan menggunakan soil sampling ring ukuran diameter $5 \mathrm{~cm}$ dan tinggi $7 \mathrm{~cm}$ dengan meratakan dan membersihkan lapisan atas tanah yang akan diambil.

2. Ring dimasukkan kedalam tanah secara perlahan agar tanah tidak rusak dengan cara menekan permukaan tabung.

3. Tanah digali pada sekeliling tabung/ring untuk memudahkan pengambilan tabung yang berisi tanah utuh.

4. Tanah diiris pada kedua sisi tabung dengan pisau/cutter kemudian tabung ditutup pada kedua sisinya dan diberi label/kode sampel.

5. Analisis dilakukan di laboratorium tanah UGM untuk mengetahui tekstur dan permeabilitas.

Pengambilan sampel tanah tidak utuh secara komposit dilakukan untuk menganalisis sifat kimia tanah yaitu BO, $\mathrm{N}$-tot, dan $\mathrm{pH}$. Tahapan dilakukan sebagai berikut:

1. Tanah digali sampai pada kedalaman yang diinginkan yaitu kedalaman $0-15 \mathrm{~cm}$.

2. Tanah dimasukkan kedalam kantong plastik yang sudah disiapkan dan beri nomor dan label serta diikat dan simpan untuk selanjutnya dianalisis di laboratorium.

3. Khusus untuk analisis aktivitas organisme tanah, sampel tanah yang diambil dari setiap plot pengamatan diletakkan dalam kotak pendingin untuk menjaga keutuhan mikroba tanah selanjutnya dianalisis di laboratorium untuk mengetahui tingkat respirasi.

4. Tanah komposit digunakan untuk menganalisis sifat kimia tanah antara lain: $\mathrm{BO}, \mathrm{N}$-tot, dan $\mathrm{pH}$. 


\subsection{Permeabilitas Tanah}

Permeabilitas tanah dapat diartikan kemampuan air menembus tanah pada periode tertentu dan dinyatakan dalam $\mathrm{cm} /$ jam (Henry D, 1978). Permeabilitas penting dalam menentukan penggunaan dan pengelolaan praktis tanah. Permeabilitas mempengaruhi penetrasi akar, laju penetrasi air, laju absorpsi air, drainase internal dan pencucian unsur hara (Donahue, 1984). Faktor-faktor yang mempengaruhi permeabilitas tanah antara lain tekstur tanah, porositas dan distribusi ukuran pori, stabilitas agregat dan stabilitas struktur tanah serta kadar bahan organik tanah (Hudson, 1976).

\subsection{Tekstur Tanah}

Tekstur tanah dapat ditunjukkan dari kasar halusnya tanah, berdasarkan perbandingan pasir (sand), debu (silt) dan liat (clay). Fraksi pasir berukuran $(2 \mathrm{~mm}-50 \mu)$ lebih kasar dibanding debu $(50 \mu-2 \mu)$ dan liat (lebih kecil dari $2 \mu$ ). Karena ukurannya kasar, maka tanah-tanah yang didominasi oleh fraksi pasir seperti tanah-tanah yang tergolong dalam sub-ordo Psamment, akan melalukan air lebih cepat (kapasitas infiltrasi dan permeabilitas tinggi) dibandingkan dengan tanah-tanah yang didominasi oleh fraksi debu dan liat. Kapasitas infiltrasi dan permeabilitas yang tinggi, serta ukuran butir yang relatif lebih besar menyebabkan tanah-tanah yang didominasi oleh pasir umumnya mempunyai tingkat erodibilitas tanah rendah. Tanah dengan kandungan pasir halus $(0,01$ $\mathrm{mm}-50 \mu$ ) juga mempunyai kapasitas infiltrasi cukup tinggi, akan tetapi jika terjadi aliran permukaan, maka butir-butir halusnya akan mudah terangkut (Wischmeier W. H. and J. V. Mannering, 1969).

Debu merupakan fraksi tanah yang mempunyai ukuran relative halus. Berbeda dengan debu, liat meskipun berukuran halus, namun mempunyai muatan maka fraksi ini dapat membentuk ikatan. Tanah bertekstur halus yang didominasi liat umumnya bersifat kohesif sangat sulit untuk dihancurkan. Kemampuan curah hujan atau aliran permukaan bias menghancurkan ikatan antar partikelnya, sehingga menimbulkan bahan sedimen tersuspensi yang mudah hanyut terbawa oleh aliran permukaan (Meyer, L.D. and Harmon, 1984).

Fraksi halus dari sedimen yang tersuspensi dapat menutupi pori-pori lapisan permukaan tanah. Akibatnya infiltrasi akan menurun sehingga aliran permukaan akan meningkat. Akan tetapi, jika tanah demikian mempunyai agregat yang mantap, tidak mudah terdispersi, maka penyerapan air ke dalam tanah masih cukup besar, sehingga aliran permukaan dan erosi menjadi relatif tidak berbahaya (Arsyad, S. 2006).

\subsection{Struktur/ Agregasi Tanah}

Bentuk dan stabilitas agregat, serta persentase tanah yang teragregasi sangat berperan dalam menentukan tingkat kepekaan tanah terhadap erosi. Tanah yang paling peka terhadap erosi adalah tanah yang paling rendah persentase agregasinya (poor aggregated). Tanah dengan tingkat gregasi tinggi, berstruktur kersai atau granular, sarang, tingkat penyerapan airnya lebih tinggi dari pada tanah yang tidak berstruktur atau susunan butir-butir primernya lebih rapat (Ai Dariah et al, 2019).

Selain dipengaruhi oleh tekstur dan kandungan bahan organik, pembentukan agregat tanah dipengaruhi oleh jumlah dan jenis kation yang diadsorbsi liat. Pengaruh kandungan besi dan aluminium oksida terhadap tingkat erodibilitas tanah, erat hubungannya dengan pembentukan dan penstabilan agregat tanah (Ai Dariah et al, 2019).

\subsection{Bahan Organik}

Bahan Organik berperan untuk pembentukan dan pengikatan serta penstabilan agregat tanah. Pengikatan dan penstabilan agregat tanah oleh bahan organik melalui pengikatan secara fisik butir primer tanah oleh jamur mycelia jamur, actinomycetes, serta akar halus tanaman. Gugus-gugus aktif dari bahan organik tanah, misalnya gugus negatif (carboxyl) pada senyawa organik berantai panjang, atau gugus positif (gugus amine, amide, atau amino) pada senyawa organik berbentuk rantai (polymer) diikat secara kimia (Veiche, 2002).

Bahan organik berbentuk serasah, seperti daun, ranting yang menutupi permukaan tanah, sebagai pelindung tanah terhadap kekuatan butir-butir hujan yang jatuh. Bahan organik dapat menghambat aliran permukaan, sehingga kecepatan alirannya lebih lambat sehingga tidak bersifat merusak. Pengaruh yang paling utama adalah bahan organik dapat memperlambat aliran permukaan, meningkatkan infiltrasi, dan memantapkan agregat tanah (Wischmeier W. H. and J. V. Mannering, 1969).

\subsection{Pendugaan Erosi Tanah}

Perkiraan jumlah tanah erosi ditentukan menggunakan rumus Universal Soil Loss Equation (USLE) Persamaan 1.

$$
A=R \times K \times L S \times C \times P
$$


Analisis dengan perhitungan rumus USLE digunakan sebagai pembanding hasil data setiap sampel yang diperoleh pertanggal kejadian hujan dari erosi aliran permukaan yang terjadi dilokasi observasi.

\section{a. Faktor Erosivitas Hujan (R)}

Erosivitas merupakan daya hujan untuk menimbulkan erosi pada tanah. Semakin besar erosivitas maka semakin besar jumlah tanah yang tererosi (berbanding lurus). Indeks erosivitas curah hujan ditentukan untuk setiap satuan lahan tersebut di atas. Data curah hujan yang digunakan dalam penelitian meliputi rata-rata tahunan periode tahun 2015 sampai tahun 2018. Perhitungan faktor erosivitas hujan ditentukan dengan menggunakan Persamaan 2.

$$
R=0,548257 \times P-59,9
$$

Dimana $\mathrm{P}=$ curah hujan tahunan $(\mathrm{mm})$

\section{b. $\quad$ Faktor Erodibilitas Tanah $(\mathbf{K})$}

Sifat-sifat fisik tanah seperti tekstur, persentase bahan organik, struktur, dan permeabilitas sangat berpengaruh pada erodibilitas tanah. Umumnya tanah dengan erodibilitas rendah mempunyai proporsi pasir halus dan debu rendah, kandungan bahan organik yang tinggi, struktur yang baik dan tingkat infiltrasi yang tinggi. menghitung erodibilitas tanah Persamaan 3.

$$
\mathrm{K}=\frac{2,173 \times\left(2,1 \times \mathrm{M}^{1,14} \times\left(10^{-4}\right) \times(12-\mathrm{a})+3,25 \times(\mathrm{b}-2)+2,5 \times(\mathrm{C}-3)\right)}{100}
$$

Dimana $\mathrm{K}=$ Faktor erodibilitas tanah (ton.ha.thn), $\mathrm{M}=(\%$ debu $+\%$ pasir sangat halus $) \mathrm{x}(100-\%$ lempung), a $=$ persentase bahan organic $(\% \mathrm{C} \times 1,724), \mathbf{b}=$ kelas struktur tanah, $\mathrm{C}=$ kelas permeabilitas tanah.

\section{c. Faktor Panjang dan Kemiringan Lereng (LS)}

Nilai L dan S biasanya dihitung secara bersamaan. LS merupakan rasio antara besarnya erosi dari sebidang tanah dengan panjang lereng dan kecuraman tertentu terhadap besarnya erosi dari sebidang tanah yang identik terletak pada lereng dengan panjang $(\lambda)$ dan kecuraman $\left(^{\circ}\right)$. Nilai LS dengan Persamaan 4

$$
\mathrm{LS}=\left(\frac{\lambda}{22,13}\right)^{\mathrm{m}} \times\left(65,41 \times \operatorname{Sin}^{2} \theta+4,56 \times \operatorname{Sin} \theta+0,065\right)
$$

Dimana $\lambda=$ panjang slope di lapangan, $\mathrm{m}=$ konstanta tergantung dari kemiringan lereng $(\mathrm{m}=0,2$ untuk $<1 \%, \mathrm{~m}$ $=0,3$ untuk $=1-3 \%, \mathrm{~m}=0,4$ kemiringan $=3,5-4,5 \%$, dan $\mathrm{m}=0,5$ untuk $>5 \%), \theta=$ sudut kemiringan

\section{d. Faktor Pengelolaan Tanaman (C), Faktor Pengelolaan Konservasi (P)}

Faktor koefisien vegetasi/tanaman (C) dan pengelolaan lahan (P) mengacu pada hasil karakteristik satuan lahan dikawasan lokasi daerah penelitian.

\subsection{Kelas Tingkat Bahaya Erosi}

Erosi tahunan rata-rata dipertimbangkan untuk menentukan tingkat bahaya erosi yang terjadi untuk tiap satuan plot lahan pada lokasi observasi. Tabel 1. 
Tabel 1.Tingkat Erosi Kehilangan Tanah Tahunan Rata-Rata

\begin{tabular}{lll}
\hline No & Tingkat kehilangan tanah (ton/ha/th) & Tingkat erosi \\
\hline 1 & $<10$ & Rendah \\
2 & $10-50$ & Sedang \\
3 & $50-200$ & Tinggi \\
4 & $>200$ & Sangat Tinggi
\end{tabular}

Sumber : Meyer, L.D. and Harmon, 1984

\section{HASIL DAN PEMBAHASAN}

\subsection{Tingkat Erodibilitas Tanah}

Untuk menganalisis tingkat erodibilitas tanah di daerah penelitian terlebih dahulu dibuat satuan medan yang dijadikan sebagai satuan analisis. Tanah merupakan faktor utama dalam penyusunan satuan medan yang dibuat untuk penjabaran dari suatu jenis tanah yang berkembang dalam bentuk lahan serta penggunaan lahan tertentu. Satuan lahan diperoleh dari sifat-sifat tanah, bentuk lahan, lereng, dan penggunaan lahan (Ahmad dan Agung R., 2015).

Nilai erodibilitas tanah ditentukan oleh berbagai faktor. Tekstur berkaitan dengan kapasitas infiltrasi serta kemudahan tanah untuk terangkut pada saat terjadi erosi. Bahan organik selain menyuburkan tanah juga memperkuat agregat tanah. Struktur merupakan susunan saling mengikat antar butir tanah sehingga semakin kuat struktur maka semakin tahan terhadap erosi. Klasifikasi tingkat erodibilitas tanah dapat dilihat pada Tabel 2. Permeabilitas berkaitan dengan kemampuan tanah meloloskan air (Ahmad dan Agung R., 2015).

Tingkat erodibilitas didaerah penelitian terbilang tinggi lihat hasil Tabel 3. Karena dilihat dan diperkirakan dari kemiringan tanah berkisar $15-25^{\circ}$.

Sehingga pengelolaan sistem lahan perlu secara intens. Karena tingkat erosi pada tanah daerah penelitian terbilang besar. Lihat hasil Tabel 4.

Faktor erodibilitas menunjukkan kemudahan tanah mengalami erosi, semakin tinggi nilainya semakin mudah tanah tererosi. Tinggi faktor erodibilitas antara satu tempat dengan tempat yang lain disebabkan kondisi tekstur tanah. Tekstur berperan dalam erodibilitas tanah, partikel berukuran besar tahan terhadap daya angkut karena ukurannya sedangkan partikel halus tahan terhadap daya penghancur karena daya kohesifitasnya. Partikel yang kurang tahan terhadap keduanya adalah debu dan pasir sangat halus (Morgan, R.C.P., 1986).

Topografi berperan menentukan kecepatan dan volume limpasan permukaan serta erosi. Dua unsur topografi yang berperan adalah panjang lereng dan kemiringan lereng. Semakin miring suatu lereng maka butir-butir tanah yang terpercik kebawa oleh tumbukan butir-butir hujan akan menyebabkan laju erosi semakin tinggi (Arsyad, S., 2006).

Tabel 2. Klasifikasi tingkat erodibilitas tanah

\begin{tabular}{lll}
\hline Kelas & Nilai K & Tingkat Erodibilitas \\
\hline 1 & $0,00-0,10$ & Sangat rendah \\
2 & $0,11-0,21$ & Rendah \\
3 & $0,22-0,32$ & Sedang \\
4 & $0,33-0,44$ & Agak tinggi \\
5 & $0,45-0,55$ & Tinggi \\
6 & $0,56-0,64$ & Sangat tinggi \\
\hline
\end{tabular}


Tabel 3. Nilai erodibilitas (K) tanah lahan penelitian

\begin{tabular}{|c|c|c|c|c|c|c|c|}
\hline \multirow[t]{2}{*}{ Kode } & BO & Debu & $\begin{array}{l}\text { Pasir } \\
\text { Halus }\end{array}$ & $\begin{array}{l}\text { Lempun } \\
\mathrm{g}\end{array}$ & $\begin{array}{l}\text { Permeabilita } \\
\text { s (cm/jam)* }\end{array}$ & $\begin{array}{l}\text { Struktur } \\
\text { Tanah } \\
(\mathbf{m m})\end{array}$ & \multirow[t]{2}{*}{$\mathbf{K}$} \\
\hline & $\%$ & $\%$ & $\%$ & $\%$ & Nilai (p) & Nilai (s) & \\
\hline Disposal jute net k1 & 0,68 & 34,67 & 11,60 & 42,04 & 1,01 & 1 & 0,40 \\
\hline Disposal jute net k2 & 0,82 & 33,31 & 11,71 & 38,98 & 0,01 & 1 & 0,44 \\
\hline Disposal jute net k3 & 0,55 & 30,48 & 15,84 & 39,93 & 0,28 & 1 & 0,43 \\
\hline Disposal non jute net $\mathrm{k} 1$ & 0,41 & 38,78 & 8,08 & 50,03 & 0,01 & 1 & 0,46 \\
\hline Disposal non jute net $\mathrm{k} 2$ & 1,37 & 41,84 & 10,14 & 40,61 & 0,93 & 1 & 0,45 \\
\hline Disposal non jute net $\mathrm{k} 3$ & 0,97 & 34,46 & 11,98 & 44,51 & 0,93 & 1 & 0,45 \\
\hline Inpit jute net $\mathrm{k} 1$ & 2,87 & 27,90 & 25,13 & 34,61 & 4,08 & 1 & 0,43 \\
\hline Inpit jute net $\mathrm{k} 2$ & 1,23 & 27,88 & 19,79 & 15,18 & 2,04 & 1 & 0,42 \\
\hline Inpit jute net $\mathrm{k} 3$ & 1,91 & 27,32 & 24,74 & 31,81 & 3,76 & 1 & 0,42 \\
\hline Inpit non jute net $\mathrm{k} 1$ & 0,82 & 28,80 & 26,13 & 28,01 & 35,01 & 1 & 0,46 \\
\hline Inpit non jute net $\mathrm{k} 2$ & 2,2 & 29,40 & 25,31 & 35,75 & 29,40 & 1 & 0,45 \\
\hline Inpit non jute net $\mathrm{k} 3$ & 2,05 & 29,61 & 25,66 & 37,81 & 29,10 & 1 & 0,44 \\
\hline
\end{tabular}

* Note : Nilai Permeabilitas hasil sample tanah di Lab. Tanah Fak. Pertanian UGM

\subsection{Pengukuran Erosi Sedimentasi}

Hasil pengukuran erosi sedimentasi dan aliran permukaan pada lokasi lereng disposal setiap kejadian hujan selama bulan Desember 2017 s/d Maret 2018. Sedimentasi pada plot pengamatan di lokasi disposal jute net, dihasilkan nilai tertinggi rata-rata sebesar $166,44 \mathrm{gr} / \mathrm{m} 2$, dan nilai terendah rataa-rata sebesar 2,02 gr/m2. Sedimentasi pada plot pengamatan di lokasi disposal non jute net dihasilkan nilai tertinggi rata-rata sebesar $417,66 \mathrm{gr} / \mathrm{m} 2$, dan nilai rata-rata terendah $2,81 \mathrm{gr} / \mathrm{m} 2$.

Sedimentasi pada plot pengamatan di lokasi in pit jute net, dihasilkan nilai tertinggi rata-rata sebesar 65,88 $\mathrm{gr} / \mathrm{m} 2$, dan nilai terendah rata-rata sebesar $1,23 \mathrm{gr} / \mathrm{m} 2$. Sedimentasi pada plot pengamatan di lokasi in pit non jute net dihasilkan nilai tertinggi rata-rata sebesar 823,73 gr/m2, dan nilai rata-rata terendah $0,71 \mathrm{gr} / \mathrm{m} 2$. Erosi tanah yang terjadi setiap habis hujan dituliskan pada table yang telah dibuatkan kemudian dikumpulkan pada botol yang telah diberi tanda kode sesuai lokasi dan tanggal pengambilan data. Disajikan dalam grafik Gambar 4.

Penelitian dilakukan saat musim hujan tertinggi dimana pengamatan erosi akan lebih ideal karena pengambilan data dilakukan langsung di lapangan sesuai dengan kondisi aktual di area penelitian. Di lokasi disposal dan in pit memiliki tekstur pasir halus, debu dan liat umumnya fraksi ini mempunyai muatan dan dapat membentuk ikatan bersifat kohesif dan sulit untuk dihancurkan. Akan tetapi karena kekuatan curah hujan yang mampu menghancurkan ikatan antar partikelnya yang menyebabkan timbul bahan sedimen tersuspensi yang terangkat terbawa aliran permukaan.

Curah hujan yang mempunyai intensitas tinggi akan meningkatkan laju erosi yang terjadi pada permukaan tanah. Gumpalan tanah yang pecah karena benturan air hujan akan menyebabkan butiran tanah terangkut oleh aliran permukaan tanah dari hujan (Arsyad, S., 2006). Saat dilakukan pengamatan di lokasi penelitian, intensitas curah hujan sangat tinggi pada saat dilakukan penelitian. Hal tersebut yang mempengaruhi besaran erosi tanah yang terjadi. Dapat dilihat Gambar 5. 


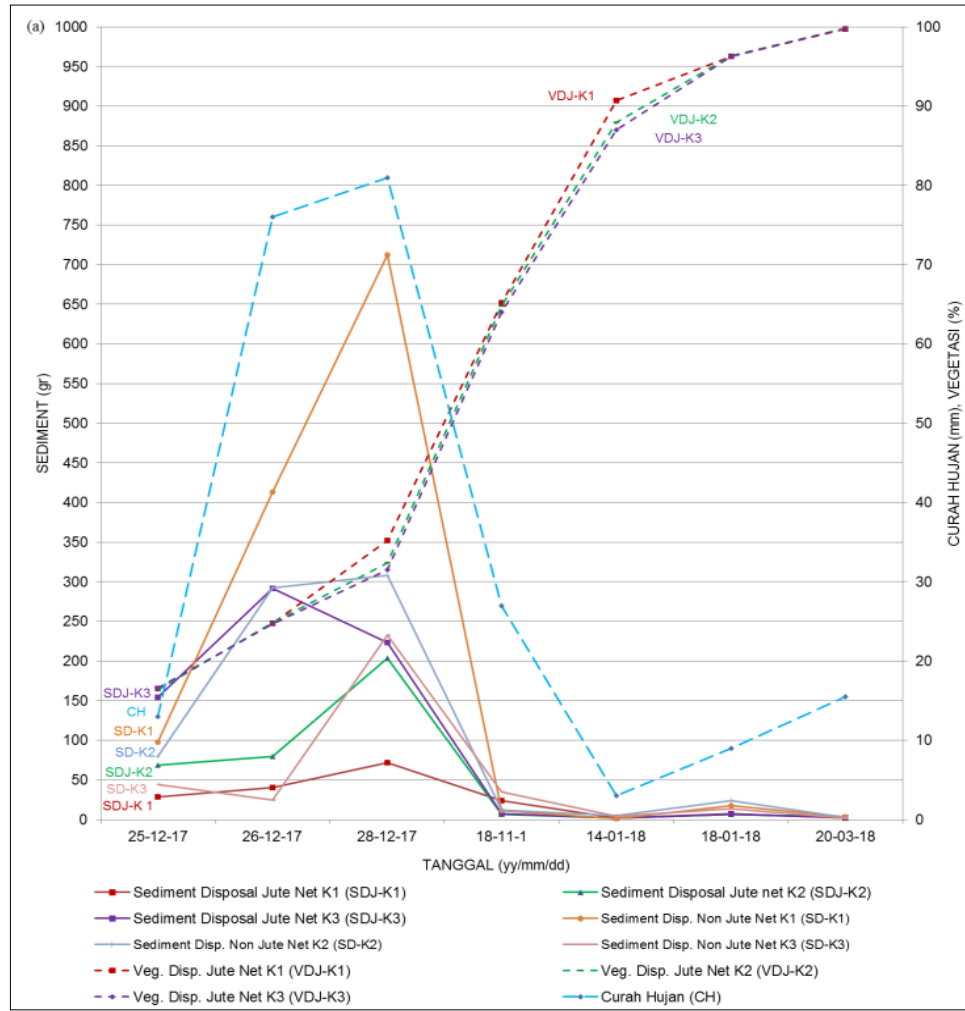

(a)

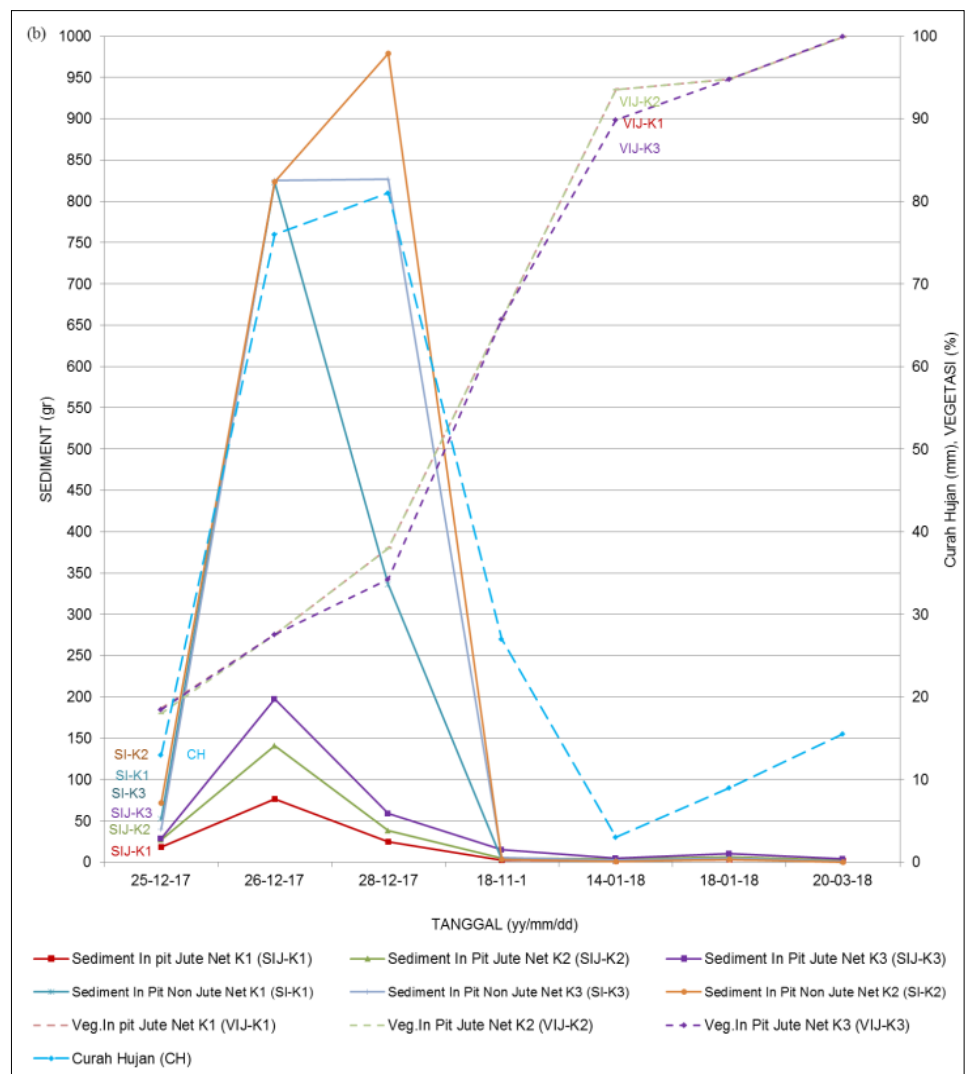

(b)

Gambar 4. (a) Kurva Erosi Lokasi Disposal Jute Net., Kurva Erosi Lokasi Disposal Non-Jute Net. (b)Kurva Erosi Lokasi Low Wall In Pit Jute Net., Kurva Erosi Lokasi Low Wall In Pit Non-Jute Net

Faktor alami yang mempengaruhi erosi dapat dirinci dari pengaruh yang disumbangkan terhadap proses erosi dan sedimentasi. Besarnya erosi dipengaruhi oleh beberapa faktor yaitu curah hujan, lereng, vegetasi, sifat tanah, dan penggunaan lahan (Morgan, R.C.P., 1986). 


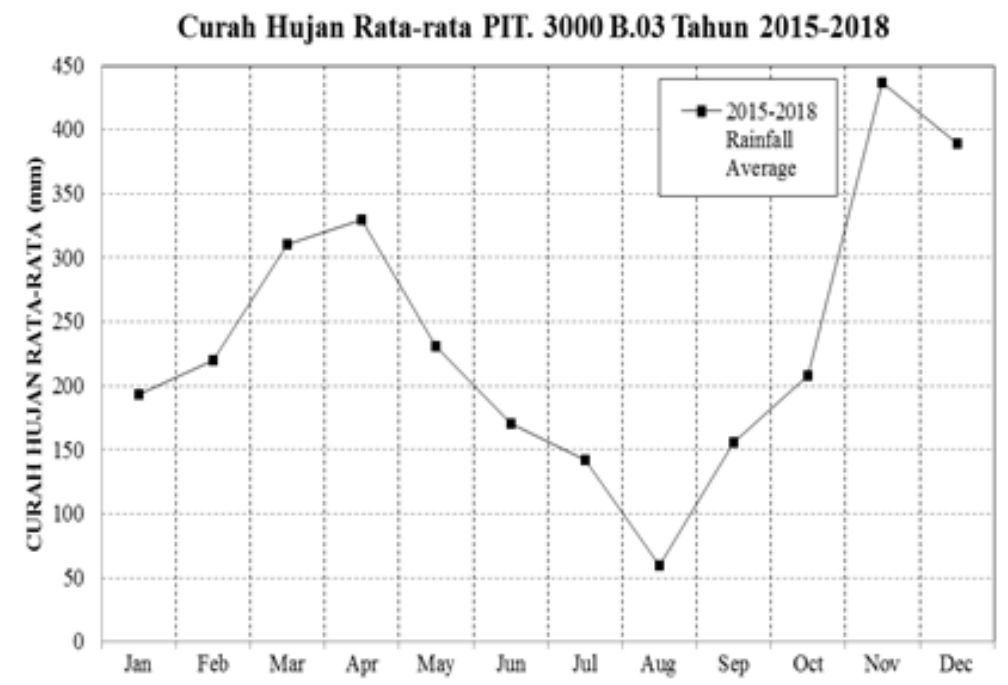

Gambar 5. Kurva Curah Hujan Rata-Rata di PIT 3000 B.03 Sebagai Lokasi Observasi

\subsection{Bahan Organik}

Penambahan bahan organik kedalam tanah lebih kuat pengaruhnya kearah perbaikan sifat-sifat tanah, khususnya untuk meningkatkan unsur hara dalam tanah. Kandungan bahan organik di wilayah penelitian tergolong rendah $(0,41-2,87) \%$ akibat dari hujan yang berlangsung intensif dan sebagian terbawa erosi. Bahan organik yang tergolong rendah menyebabkan tekstur tanah yang dominan pasir halus dan liat mempengaruhi stabilitas agregat/ struktur tanah yang akhirnya membuat pori mudah hancur sehingga tanah mudah tersuspensi oleh aliran permukaan sehingga menghasilkan sedimen.

\subsection{Tingkat Bahaya Erosi}

Metode perhitungan USLE besar erosi pada lokasi disposal jute net sebesar 944.56 ton/ha, disposal non jute net sebesar 1016.81 ton/ha. Lokasi in pit jute net erosi sebesar 1805.31 ton/ha, in pit non jute net erosi sebesar 1917.10 ton/ha. Dari hasil penelitian menggunakan perhitungan USLE didapati hasil erosi sangat tinggi. Hasil perhitungan USLE ini sangat terpengaruh oleh data curah hujan tahunan serta sifat fisik tanah.

Nilai curah hujan yang digunakan dalam perhitungan erosivitas dan sifat-sifat tanah yang digunakan dalam perhitungan erodibilitas sangat mempengaruhi hasil perhitungan nilai erosi. Pada lokasi penelitian tekstur tanah geluh lempung pasiran dengan kelas permeabilitas sangat cepat, ini sebagai salah satu penyebab tingginya tingkat erosi yang terjadi.

Tabel 4. Nilai prediksi erosi tahunan menggunakan metode perhitungan USLE

\begin{tabular}{|c|c|c|c|c|}
\hline No & Kode & Lereng $(\%)$ & $\begin{array}{l}\text { Erosi dalam USLE } \\
\text { (ton/ha/thn) }\end{array}$ & Tingkat Erosi \\
\hline 1 & Disposal jute net k1 & 26,79 & 896.98 & Sangat tinggi \\
\hline 2 & Disposal jute net k2 & 26,79 & 978.60 & Sangat tinggi \\
\hline 3 & Disposal jute net k3 & 26,79 & 958.09 & Sangat tinggi \\
\hline 4 & Disposal non jute net k1 & 26,79 & 1024.72 & Sangat tinggi \\
\hline 5 & Disposal non jute net $\mathrm{k} 2$ & 26,79 & 1012.39 & Sangat tinggi \\
\hline 6 & Disposal non jute net k3 & 26,79 & 1013.32 & Sangat tinggi \\
\hline 7 & In pit jute net $\mathrm{k} 1$ & 46,63 & 1833.05 & Sangat tinggi \\
\hline 8 & In pit jute net $\mathrm{k} 2$ & 46,63 & 1801.78 & Sangat tinggi \\
\hline 9 & In pit jute net $\mathrm{k} 3$ & 46,63 & 1781.10 & Sangat tinggi \\
\hline
\end{tabular}




\begin{tabular}{lllll}
\hline 10 & In pit non jute net k1 & 46,63 & 1981.49 & Sangat tinggi \\
11 & In pit non jute net k2 & 46,63 & 1908.88 & Sangat tinggi \\
12 & In pit non jute net k3 & 46,63 & 1860.93 & Sangat tinggi \\
\hline
\end{tabular}

\section{KESIMPULAN}

1. Nilai erodibilitas tanah pada lokasi penelitian masuk tingkat erodilibitas tanah agak tinggi rata-rata 0,44 .

2. Nilai erodiblitas tanah dipengaruhi oleh sifat-sifat tanah dilokasi penelitian, dengan tekstur tanah debu dan pasir halus yang mudah tererosi saat curah hujan turun. Aliran permukaan akan mudah mengangkut butirbutir halusnya.

3. Struktur/agregasi tanah pada lokasi penelitian termasuk agregasinya paling rendah menyebabkan tanah sangat peka terhadap erosi dengan kelas granular sangat halus.

4. Bahan organik di wilayah penelitian tergolong rendah $(0,41-2,87) \%$ akibat dari hujan yang berlangsung intensif dan sebagian terbawa erosi oleh aliran permukaan.

5. Metode perhitungan USLE besar erosi pada lokasi disposal jute net sebesar 944.56 ton/ha, disposal non jute net sebesar 1016.81 ton/ha. Lokasi in pit jute net erosi sebesar 1805.31 ton/ha, in pit non jute net erosi sebesar 1917.10 ton/ha. Tingkat bahaya erosi di lokasi penelitian tergolong sangat tinggi, dengan kehilangan tanah $>200$ (ton/ha/thn).

\section{UCAPAN TERIMA KASIH}

Penulis ingin mengucapkan terima kasih kepada rekan-rekan kerja di PT. Trubaindo Coal Mining atas support data dan dukungannya. Terima kasih untuk Pembimbing akademik Fakultas Teknologi Mineral, UPN Veteran Yogyakarta, Indonesia yang telah membimbing dalam ilmu yang diberikan hingga selesai penulisan paper.

\section{DAFTAR PUSTAKA}

Aafaf El Jazouli, Ahmed Barakat, Abdessamad Ghafiri, Saida El Moutaki, Abderrahim Ettaqy, Rida Khellouk. (2017). Soil erosion modeled with USLE, GIS, and remote sensing: a case study of Ikkour watershed in Middle Atlas (Morocco) Geosci. Lett., from Doi 10.1186/s40562-017-0091-6.

Abu bakar, F. (2009). Evaluasi tingkat keberhasilan revegetasi lahan bekas tambang nikel di PT. INCO tbk, Sorowako, Sulawesi Selatan. Bogor: Institut Pertanian Bogor.

Ai Dariah, Subagyo, Chendy Tafakresnanto, Setiari Marwanto. (2019). Kepekaan tanah terhadap erosi.

Arsyad, S. (2006). Konservasi tanah dan air. Lembaga Sumberdaya Informasi Institut Pertanian Bogor. Bogor: IPB Press.

Asma Belasri, \& Abdellah Lakhouili. (2016). Estimation of soil erosion risk using the universal soil loss equation (USLE) and geo-information technology in Oued El Makhazine Watershed, Morocco. Journal of Geographic Information System, Vol.08, (98-107)., from Doi : 10.4236/ jgis. 2016. 81010.

David Hernando, \& Manuel G. Romana. (2015). Development of a soil erosion classification system for cut and fill slopes. Transp. Infrastruct. Geotech 2: (155-166)., from DOI 10.1007/s40515-015-0024-9.

Donahue, R.L, (1984). Soil and introduction to soil and plant growth printice hall Inc. Engelwood Clifts. New York.

Henry D. Foth. (1978). Fundamentals of soil science (6th ed). New York: John Willey and Sons.

Hudson, N. (1976). Soil conservation. London: B.T. Batsford Limited.

Hudson, W.W. (1976). Soil conserfation. London: BT. Batsford Limited.

Ibnu Khabibi Ahmad, \& Agung R. (2015). Observasi erodibilitas tanah Kampus II UIN Cimencrang. Bandung: Jurusan Agroteknologi UIN Sunan Gunung Djati Bandung.

Liebenow, A. W. J. M. Laflen, K. D. Kohl. (1990). Interill erodibility: Collection and analysis of data from cropland soil. Am. Soc. Agric. Eng. 33 (6): 1.882-1.887. 
Maryani, I.S. (2007). Dampak penambangan pasir pada lahan hutan alam terhadap sifat fisik, kimia, dan biologi tanah (studi kasus di Pulau Sebaik Kabupaten Karimun Kepulauan Riau). Skripsi. Institut Pertanian Bogor.

Meyer, L.D., \& Harmon. (1984). Susceptibility of agricultural soils to interill erosion. Soil Sci. Soc. Am.J. 8:1. 152-157.

Morgan, R.C.P. (1986). Soil erosion. London and New York: Longman.

S.Dutta. (2016) Soil erosion, sediment yield and sedimentation of reservoir. Model. Earth Syst. Environ 2:123., from Doi 10.1007/s40808-016-0182-y.

Tung gia pham, Jan Degener, Martin kappas. (2018) Integrated universal soil loss equation (USLE) and Geographical Information System (GIS) for soil erosion estimation in A Sap Basin: Central Vietnam. ISWCR, Vol.6 : 99-110., from Doi. org/ 10.1016/ j.iswcr. 2018. 01. 001.

Veiche, A. (2002). The spasial variability of erodibility and its relation to soil types : A study from Northem Ghana. Geoderma 106 : 110-120.

Wischmeier, W. H., \& J. V. Mannering. (1969). Relation of soil properties to its erodibility. Soil Sci. Am. Proc. 33: 131-137. 